\section{Promote Local Culture and Products}

\section{Rosalba Thomas Muñoz}

University Center for Social Research, School of Philosophy, University of Colima, Colima, Mexico

\section{Synonyms}

Culture: A high level of taste and enlightenment as a result of extensive intellectual training and exposure to the arts; the way people live at a particular time and place (accomplishment, civilization, couth, cultivation, polish, refinement; civilization, life, lifestyle, society) https://www. merriam-webster.com/thesaurus/culture (as of $12 / 27 / 18)$

\section{Definition}

Cultural evolution is a process that derives from the biological evolution of the human being. The latter has placed man as the main transformer of this known universe; however, the struggle for biological survival is also a struggle for ideas as a central element of cultural evolution.

Humans fight for their ideas because their brain allows it and social interaction demands it. Biology offers potential through the brain we have, but it is culture that models it by building the world of relationships that are shared (Zapata 2014). Therefore, cultures evolve rapidly, because the human being is a social being, learns from their interaction with others, and accumulates this knowledge for their own benefit of adaptation.

Contemporary society is a society of culture to the extent that culture is at the very center of the symbolic and material re-production of social life

But, then, what is culture? According to Clyde Kluckhohn (cited in Geertz 1973, p. 19), culture can be several things:

1. "the total way of life of a people"

2. "the social legacy that the individual acquires from his group"

3. "a way of thinking, feeling and believing"

4. "an abstraction of behavior"

5. "a theory of the anthropologist on the way in which a group of people is actually conducted"

6. "a warehouse of stored knowledge"

7. "a series of standardized guidelines for repeated problems"

8. "learned behavior"

9. "a mechanism of normative regulation of behavior"

10. "a series of techniques to adapt, both to the external environment and to other men"

11. "a precipitate of history" 
However, this dispersion of the concept of culture makes the process of choosing or finding a single definition complex, precisely because there is no single theoretical solution and because, in addition, it should not be chosen.

For Cliford Geertz (1973), culture is "not an experimental science in search of laws, but an interpretative science in search of meanings." Therefore, the important thing is not the definition, but the possibility of knowing the meanings and expressions that have the human groups and the behaviors that they entail.

On the other hand, a local culture lodges diverse meanings and social expressions of groups that are identified with a limited physical space, maintain a physical and human geography with certain characteristics and interactions between organisms, based on a certain way of life, language, beliefs, social organization, among others. However, just as there is no single definition of culture, so all cultures are a mixture of previous expressions. There is no pure culture, but these are constantly changing and evolving.

Speaking concretely of local cultures, these have an importance and relevant characteristics because they involve the roots of the behavior of a specific group, they mark a rhythm in front of the decision making, and they establish warning signs against injustices and inequalities to which the homogenization of the thought imposes us.

Despite living in constant change and adaptation, local cultures recognize the close relationship of the human being with nature, not only because this relationship allows us to develop a biological evolution, but because with it we satisfy our basic survival and adaptation needs; so if we maintain a healthy relationship with nature as the basis for the welfare and sustainability of the planet, we will have a much more dignified and prosperous future individually and collectively.

\section{The Natural Context of Culture}

This evident relationship of the human being with nature causes different cultural expressions, derived, in large part, by the environment in which they live, that is, the ecosystems. These are considered as scenarios in which organisms with certain biological characteristics live, which share the same habitat, maintain relationships of interdependence, and form food or trophic chains. One example is terrestrial ecosystems: forests, grasslands, deserts, and poles, which have certain types of physical and human geography; so the organisms that live there also have certain characteristics and behaviors. Another example is the marine ecosystems: estuaries (or mouths of rivers) and continental waters (or bodies of fresh water), where other types of animals live and other trophic chains occur. And finally, there are the urban ecosystems: artificial and semiartificial, in which the existence of human beings predominates.

In these conditions, it is evident that the behavior of an organism will not be the same if it lives in zones with cold climates to others accustomed to a tropical climate or with an arid or mountainous geography, reason for which, its form to adapt to the place, will be a function of their biological capabilities, that is, biological evolution is a process of adaptive changes. "The struggle [in this case of the human being], to adapt to new and/or changing environments is the fact that drives their evolutionary process" (Zapata 2014). That is why for two million years, humans have had to adapt to compensate their physical weaknesses against other stronger and more dangerous predators.

Humans, then, have maintained the connection with the natural biological species, since we are not the chosen species but a species like any other (Arzuaga 2001); at the same time, we have transcended that natural world by giving rise to the cultural world from the evolution cerebral, complex cognition, and social interaction (Zapata 2014).

In this long evolutionary journey, human beings have had to develop tools, get up on two feet, develop language, and conform to increasingly complex social groups. The organ that helped them make all these material and social changes was the brain, which has had an increasingly complex development, resulting in a greater capacity for learning that allows them to 
understand and challenge the world in which they live, to group with others, and be aware of themselves.

Cultural evolution introduces the intention and
purpose in human actions, is based on thought,
language and the generation of ideas that leads to
the genesis of norms, morality and ethics seeking to
regulate social interaction. It supports the produc-
tion of instruments to transform the nature from
which it comes and achieve a material development
that allows a better individual and social well-being
(Zapata 2014)

However, this cultural evolution is much faster than the biological one and produces a cumulative knowledge at the service of the same human being; it is also difficult and complex, since it is based on adaptations to permanent and rapid changes. "Biology offers potential through the brain, but it is culture that shapes it by building the world of relationships that we share" (Zapata 2014).

\section{Local Cultures and Their Global Context}

The biological and cultural evolution that our species faces today goes beyond finding in technology the solution to their problems. Since cultural evolution is still the most useful tool for understanding the other, the world, and nature, it is a reordering of culture.

However, all cultures are a continuous mix of others, because, as already mentioned, there is no pure culture. The culture that is now valued - that enriches people, is considered ideal, and did not exist a while ago - has evolved from a previous one. The culture is alive, evolves, and is incredibly dynamic.

On the other hand, in spite of this dynamism, cultures adapt more and more to a globalized world, without apparent frontiers. For Giddens (2000):

Globalization is restructuring our ways of living, and in a very profound way. It is led by the West, carries the strong imprint of American political and economic power and is highly unequal in its consequences.

Some of the consequences of globalization can be seen directly in the phenomenon called global climate change, of which it is known that "their inherent risks are likely to result from our intervention" (Giddens 2000). Climate change directly affects the ecosystems of which the human being is supplied, the food he harvests, the cities in which he lives, the air he breathes, the soil he grows, the companies that produce, and the people who consume, among others.

Globalization, seen as economic, political, technological, and cultural events, has influenced not only the communications and the trade that surrounds the current life, it is also a permanent phenomenon that brings consequences equally in the daily life of small and large communities, modifying traditional family systems, food, language, decision-making, and coexistence with nature, among many other changes that impact culture.

Globalization does not have to do only with what is "out there", remote and remote from the individual. It is also a phenomenon "in here", which influences the intimate and personal aspects of our lives (Giddens 2000).

Knowing local traditions, their roots, and the way in which these cultures adapt to the global world becomes an essential point to find the senses of life in today's society. The miscegenation between cultures seeks to reinforce identity (understood as the cultural characteristics that define a socially conformed group), while allowing a point of encounter with the rest of the world, for example, achieving an exchange and negotiation between scientific and traditional knowledge, defining and agreeing on its values, deciding its form of political and social organization, valuing its language, and conserving its assets and historical heritage, among others.

The cultural differences (global-local) are so relevant that they face great challenges for their conservation and recognition. The value of a local culture is related to its particular expressions to understand the world, for example, through language, traditions, the roles of the members of a community, and their understanding of the cycles of nature and time, among others.

However, local cultures have also recovered due to the large macrosocial changes that influence daily habits. Despite this, García Canclini (1997) raises the thesis that neither modernity nor globalization annuls local cultures, but 
believes that these cannot be understood without global processes and movements.

\begin{abstract}
Expansion, as well as social and cultural renewal, have been manifested in the rapid industrial development and the growth of secondary and higher education, in the dynamism of artistic and literary experimentation throughout the 20th century, in the fluid adaptation of certain sectors to technological and social innovations, but these renewing impulses do not replace local traditions, sometimes accompany them and others come into conflict with it, although without destroying them (p. 122).
\end{abstract}

The term hybridization that García Canclini himself has developed in several texts (See: García Canclini 2009) mentions a reordering of the local culture, in which it incorporates aspects of the global for its own adaptation and survival. In this way, local cultures reorganize, evolve, and reconvert - leaving part of their traditions and ways of life, but transforming what will allow them to survive, not without first overcoming collateral conflicts, because "none of this happens without contradictions or conflicts. Cultures do not coexist with the seriousness with which we experience them in a museum when moving from one room to another" (García Canclini 1997).

That is why cultures hybridize the desired modern and [maintain] the traditional of what they do not want to give up (García Canclini 1997). Because in other cases, the persistence of traditional customs and thoughts is the result not of conscious cultural conservation but of an unequal access to the goods of modernity (García Canclini 1997, p. 122); such is the case of $49 \%$ of the world's population that cannot connect to the internet because they do not have access to the internet, despite the fact that $95 \%$ of the mobile network reaches almost all points of the planet (Statistics presented by the International Telecommunication Union of the United Nations in the report on Measurement of the Information Society, 2018.).

However, despite cultural differences in the way of appropriating the benefits of globalization, hybridity interests both hegemonic and popular sectors that also want to achieve some benefits of modernity (García Canclini 1997). On the one hand, transnational industries do not eliminate handicrafts or discard traditional languages; as well as communities learn to use modern means to communicate, make transactions, or merge graphic alternatives that allow them to enter the global economic market. Hybridization arises from an attempt to reconvert a cultural heritage (a factory, a professional training, a set of knowledge and techniques) to reinsert it into new production and market conditions (García Canclini 1997).

These new conditions allow:

Adapt products to multiple markets with different needs due to different social norms and values; a process of adaptation of migrants to a destination country; [the] correct establishment of the prices of products in different countries and markets; different distribution channels according to the market, unequal communication tools according to the market, etc. (García Canclini 1997).

If cultural differences were not so important, large companies would not spend such a large amount of money and investments in commercial strategies, because it is precisely the local values that the human being appreciates as different and unique. However, despite these successful adaptations of local cultures, the current evidence draws a reality that puts the biological and cultural evolution of humanity at risk. Globally, highly complex problems are envisaged - including ecosystem changes that go beyond biological adaptability, such as safety around water and technologies for its treatment, mapping of threatened ecosystems, recycling of waste, and reuse of wastewater, among others.

It is talking about these changes can cause serious health risks, such as resistance to viruses, antibiotics and the generation of new global diseases such as SARS, Ebola and Zika; the digitalization of human beings (biosensors and DNA sequencing); the increase of the world population in urban ecosystems, among others. Undoubtedly, these are complex problems that must be understood taking into account the qualities of a complex reality. As stated by De Sousa (2012), "we have modern problems for which we do not have modern solutions."

This variety of cultural realities is built around information. According to Berger and Luckmann (2003), the more knowledge we have about the 
phenomena that surround us, the better we can react to them to understand them, prevent them, minimize them, or solve them.

Reality is a challenge of interpretation and individual understanding, but also collective. Culture is a dynamic construct, activated in response to human life, continuously evolving tradition and convention and rooted in the social, ethnic, and accumulated heritage lifestyle (UNESCO 2011, cited in Chang et al. 2011, p. 2).

It is so then that the culture:

It is a social and historical construction that responds to the particular project that each city draws as its own. Culture is really multiculturalism; It allows the wealth of ideas and expressions, the coexistence of diverse cultures in the same territory where the recognition of the other as someone different is present. Culture is dynamic because the values that are transmitted, created and recreated remain and are combined in encounters and disagreements between different peoples or cultural constructions (INALI 2008).

In a world without borders, local culture and traditional values become more important in the accelerated process of globalization. People gradually understand that embracing their own culture is important (Chang et al. 2011, p. 3).

\section{The Local Culture and Its Value}

There are several strategies for a culture to survive or rebuild through cultural loans, adaptations, and miscegenation; so it would be impossible to say that a culture is a universal or unique reference, let alone that some cultures are subordinated to others; however, it is also a reality that:

relations between cultures have been established, historically, based on an assumption of superiority, which has led at different times and places to the disappearance of cultures of minority groups with the aim of culturally homogenizing the population. (INALI 2008, p. 18)

Cultures are diverse insofar as each person, each group, each community needs to talk about what it is, its assets, its resources, its histories, and projects, in short, its identity (UNESCO 2011). Indigenous peoples, for example, have proposals to relate to nature; they have their own ways of conceiving problems and solving them; they have a wide variety of points of view from which they look at the world; their daily life offers models to establish interpersonal and social relationships and live reciprocity, solidarity, or relationship with ancestors and even those who have not yet been born; They also teach with tenacity and persistence how deeply assumed identity is a source of energy and information for resistance.

Historically, cultures have created multiple mechanisms of expression; they achieve consensus to understand the world in which they live and manifest themselves through various dimensions, for example:

- The ways of creating, transmitting, and developing knowledge.

- Values and types of social organization.

- Language as an element that allows us to name, signify, and express the world.

- Goods and material objects that they consider their own.

All these manifestations are the product of the social relations between the communities, which form a web of multiple crossings and cultural contacts in which each member, or the group as a whole, participates for its modification and recreation.

However, when global reality monopolizes history, when we only partially know reality or do it through the media, then local knowledge becomes voiceless, lost, or disappears. Therefore, promoting a local culture means visualizing an accumulation of unrecognized reality, establishing links between different social movements to claim other types of development discourses, more attached to their own ways of thinking, expectations, and relationship with nature.

From this need to overcome the invisibility in which local cultures are found, there arises the notion of "Buen vivir" (good living), a concept originated in Latin American cultures to speak of "progress" and that takes place in the field of the critique of contemporary development. 
For Gudynas and Acosta (2011), the "Buen vivir" questions "the rationality of current development, its emphasis on economic aspects and the market, its obsession with consumption or the myth of continuous progress." Meanwhile, David Choquehuanca (2010), also argues that the "Buen vivir" is "to recover the experience of our people, recover the culture of life and recover our life in complete harmony and mutual respect with Mother Nature, with the Pachamama (concept that comes from the Quechua language: 'Pacha' can be translated as 'World' or 'Earth,' while 'mama' is equivalent to 'mother'), where everything is life, where we are all uywas, servants of nature and cosmos."

The questions about "Buen vivir" the idea of welfare understood only as a matter of economic income or material possession only solved in the market. The "buen vivir" emphasizes the quality of life, but does not reduce it to consumption or property. On the contrary, the reductionism of presenting the development of the people only as economic growth "has been strongly questioned in Latin America, warning that this is impossible, since natural resources are limited and the capacities of ecosystems to face these environmental impacts are also limited" (Gudynas and Acosta 2011).

On the other hand, local cultures produce multiple realities that are not globally visible. That is why it is necessary to recognize the presence of different languages in the world, promote the linguistic diversity that has always been present in all regions of the planet and is an elementary part of the history of humanity.

\footnotetext{
The languages spoken by the indigenous communities constitute an invaluable wealth, since each of them represents an unrepeatable experience, contains the historical memory of the people who speak it and is a vital part of their culture and identity, and is an expression of millenary cultures that sustain the pluricultural nature of the country and for that reason are an essential part of the identity (UNESCO 2011).
}

However, this cultural wealth has also been seen as a marketing product that seeks to give its surplus value in the market and which, in turn, requires adapting to the global contexts explained above; only on this occasion, a cultural product refers to "the specificity of cultural goods and services, as vectors of identity, values and meaning and should not be considered as mere products or consumer goods" (UNESCO 2011). We will further talk about traditional knowledge, which is recognized as "the wisdom, experience, skills and practices that are developed, maintained and transmitted from generation to generation within a community and that are often part of their cultural or spiritual identity" (WIPO 2012).

Traditional knowledge is generally understood as the know-how, skills, innovations, and practices developed by indigenous peoples and local communities, while traditional cultural expressions are understood as the tangible and intangible forms in which knowledge is expressed (WIPO 2012).

Currently, with the world on the verge of environmental collapse, traditional knowledge can really teach to interact with the environment in a more "sustainable" way, using natural resources without exhausting them (UNCCD 2004, p. 9). Traditional knowledge is a resource not only for local communities, but for all humanity, insofar as it allows preserving cultural diversity (Laureano 2007).

In this regard, UNESCO's Local and Indigenous Knowledge Systems (LINKS) program promotes local and indigenous knowledge and its inclusion in global climate policy and science processes. Working at the local, national, and global levels, LINKS strives to strengthen indigenous peoples and local communities, foster transdisciplinary commitments with scientists and policy makers, and develop novel methodologies to better understand the impacts of climate change, adaptation, and mitigation (UNESCO 2018).

However, in "developed" societies, the traditional knowledge and techniques that have been devised and transmitted over the centuries are now in deep crisis.

The extensive use of cement instead of local material such as land, and the use of powerful motorized pumps instead of drainage tunnels to extract groundwater in arid areas. The terraces have also 
been abandoned in favor of monocultures in the plains (UNCCD 2004).

The forms of social organization are also important as products of the local culture: Respect for the rights of peoples and their cultures to elect their political authorities; the recognition of their own governments and regulatory systems; their ways of imparting justice, fixing faults, and deciding on internal conflicts; their rights to choose their own organization for work, for the enjoyment of their resources, and for the promotion of production; and employment and the satisfaction of their needs as well as the recognition of their culture (Sámano 2011).

As part of the relationship that local cultures have with their environment, their intangible cultural heritage must also be promoted, which includes:

Practices and live expressions inherited from our ancestors and transmitted to our descendants, such as oral traditions, performing arts, social customs, rituals, festive acts, knowledge and practices related to nature and the universe, and knowledge and techniques related to the traditional crafts (UNESCO 2011).

In addition, one of the most recurrent characteristics to identify local cultures is their aspiration to find solidarity economy mechanisms. The solidarity economy is a form of production, consumption, and distribution of wealth centered on the value of the human being and not on the prioritization of capital (Gazaga 2007), which promotes partnership, cooperation, and self-management, and is oriented toward production, consumption, and marketing of goods and services in a self-managed manner, with the purpose of a wider development of life (REAS 2013).

It is possible to name many examples with this exercise of exchange of goods, services, and satisfaction of needs, such as: cooperatives; popular associations; informal groups (production, services, consumption, marketing, and even solidarity credits, both in the urban and rural areas); the companies recovered (old failed capitalist enterprises recovered by the workers); family farmers (community or family gardens); revolving credit solidarity funds; solidarity exchange clubs (with or without community currency); ecological villas; joint marketing networks and solidarity production chains; fair trade centers; green markets; and solidarity tourism agencies; among many others.

As a result of this alternative local economic system, multiple actions are generated that elevate social organization by taking into account values such as solidarity, empathy, companionship, and, above all, trust in human beings, beyond hierarchies, particular interests, money, or power.

From the above, promoting local culture is more than buying their products or giving them value in a global market; it means being able to see another reality that is invisible with the parameters of globalization; it means taking into account the history of those peoples and their relationship with nature, explore their traditions, recognize their customs, investigate the origin of their rituals, live closely their festivals, learn their myths and legends, rethink their lifestyle, value their crafts and cuisine, etc.

Finally, other ways of creating this reality that is not visible in the light of globalization and allowing local cultures to survive and adapt is through the following recommendations:

- Create and promote thematic tourism programs or products.

- Create and offer products adapted to the calendar of local events: fairs, festivals, meetings, among others.

- Organize and offer visits to traditional local festivals. It is good to know the calendar of various local festivals, fairs, traditional celebrations.

- Organize local food / beverage demonstrations: tasting homemade recipes, making homemade brandy, and making wine.

- Organize demonstrations of local handicrafts: ceramics, wood carving, hand weaving, etc.

- Offer visitors the opportunity to try to make a small souvenir for themselves.

- Organize demonstrations of local folklore: songs, dances, rituals, legends, etc. 


\section{Conclusions}

From the point of view of globalization and coexistence with local cultures, much attention must be paid to the local culture, history, traditions, and identity of a community, since they are also attractive and have a unique value for a city or municipality, making it interesting for tourists who also bring economic benefits (Doratli et al. 2004).

To preserve and promote the local culture, cultural products can be considered regional marketing channels, which provide an easy point of contact to communicate and show local culture (Chang et al. 2011).

Understanding the nature and importance of cultural heritage is a necessary condition to make strategic decisions that guarantee the cultural promotion of a place. Cultural goods are tangible and intangible, authentic and immovable evidence of human presence and activity with scientific and cultural value and with great social significance.

Local cultures store the historical memory of human societies, contribute to create national identity and cultural value, making the country recognizable and improving its image. The historical heritage must be respected for its authentic culture, its traditions and the peculiarities of the communities, promoting their preservation and development.

The conservation and exhibition of cultural, historical, and natural heritage can be promoted from various strategies of local governments and oriented to improve the quality of life in the region through the development and promotion of small businesses, such as small hotels and restaurants. Promotion activities can be directed to:

- Support citizen groups for the promotion of their traditional customs: exhibitions of traditional clothing, musical instruments, and local gastronomy.

- Create permanent and itinerant exhibitions of local ethnographic, natural, and cultural historical audiovisual heritage.
Social responsibility toward local cultures can be demonstrated by promoting better conditions and quality of tourist services; protecting the cultural heritage and the environment; encouraging and following ethical behavior to protect consumers and visitors from price speculation and protecting them against illegal competition; cooperating with local traditional food companies, buying traditional handicrafts, folk art; promoting local travel agencies; cooperating or creating networks of local organic producers, etc.; planning and scheduling routes and destinations so that visitors become familiar with and promote local heritage; organizing events, such as fairs and popular customs; and encouraging local authorities to support cultural and tourism projects; among other.

\section{Cross-References}

- Agriculture Consumption and Production

$\checkmark$ Codes of Conduct

- Fair Trade

- Future Development

- Globalization

- Green Entrepreneurship

- Green Value Chain

- Internalisation of Environmental and Social Costs

- Local and Global Environmental Sustainability

- Nonhuman Rights and Human Sustainability

- Social Manufacturing

- Social Sustainability and Continuous Learning in the Circular Economy Framework

- Stakeholder Engagement and Dialogue

- Sustainability Information Required by Consumers

- Sustainability of Local Cultures and Products

- Sustainable Consumer Lifestyles/Sustainable Consumption

- Sustainable Production

- Sustainable Societal Transitions

- Sustainable Tourism/Ecoturism 


\section{References}

Arzuaga, L. (2001). La especie elegida. La larga marcha de la evolución humana. Temas de Hoy, Madrid

Berger, P., Luckmann, T. (2003). La construcción social de la realidad. Argentina, Amorrortu

Choquehuanca, D. (2010). Bolivia: Hacia la reconstrucción del Vivir Bien. Comunicación intercultural para un mundo más humano y diverso. En: Encuentro Latinoamericano "Pachamama, Pueblos, Liberación y Sumak Kawsay”, Quito

De Sousa Santos, B. (2012). De las dualidades a las ecologías. REMTE-Red Boliviana de Mujeres Transformando la Economía, La Paz

Doratli, et al. (2004). An analytical methodology for revitalization strategies in historic urban quarters: a case study of the Walled City of Nicosia, North Cyprus. Elsevier, Great Britain, pp 329-348

García Canclini N. (1997). Culturas híbridas y estrategias comunicacionales. Estudios sobre las culturas contemporáneas III(5):109-128

García Canclini N. (2009). Culturas híbridas. Estrategias para entrar y salir de la modernidad. Grijalbo, México

Gazaga, M. (2007). La economía solidaria como forma de organización económica alternativa al sistema capitalista global. Universidad de Barcelona, Barcelona

Geertz, C. (1973). La interpretación de las culturas. Gedisa, Nueva York

Giddens, A. (2000). Un mundo desbocado. Santillana, México

Gudynas, E., Acosta, A. (2011). El buen vivir más allá del desarrollo. Quehacer 181:70-81. Recuperado de http:// www.dhl.hegoa.ehu.es/recursos/928 http://www. desco.org.pe/node/6808

INALI (2008). La diversidad cultural. Campaña nacional por la diversidad cultural de México. Instituto Nacional de Lenguas Indígenas, Ciudad de México

Laureano, P. (2007). Traditional knowledge helps combat climate. Traditional Knowledge, Word Bank

REAS (2013). Red de Economía Social y Solidaria. Pamplona

Sámano, M. (2011). Los dilemas del multiculturalismo y los pueblos indígenas en el siglo XXI. Alegatos, México, pp 1-16

Schmelkes, S. (2008). Guía didáctica sobre la diversidad cultural de México

Tsen-Yao Chang, et al. (2011). Developing cultural products to promote local culture: a marketing design for the former Tainan state magistrate residence. In: DesignEd Asia conference. Hong Kong

UNCCD (2004). Preserving our common ground: UNCCD ten years on. UN, Bonn

UNESCO (2011). Universal declaration on cultural diversity

UNESCO (2018). Conocimientos indígenas y cambio climático. https://es.unesco.org/ik-and-cc

WIPO (2012). Glossary of key terms related to intellectual property and genetic resources, traditional knowledge and traditional cultural expressions

Zapata, L. (2014). Los humanos: entre la evolución biológica y la evolución cultural. Barranquilla. Universidad del Norte 